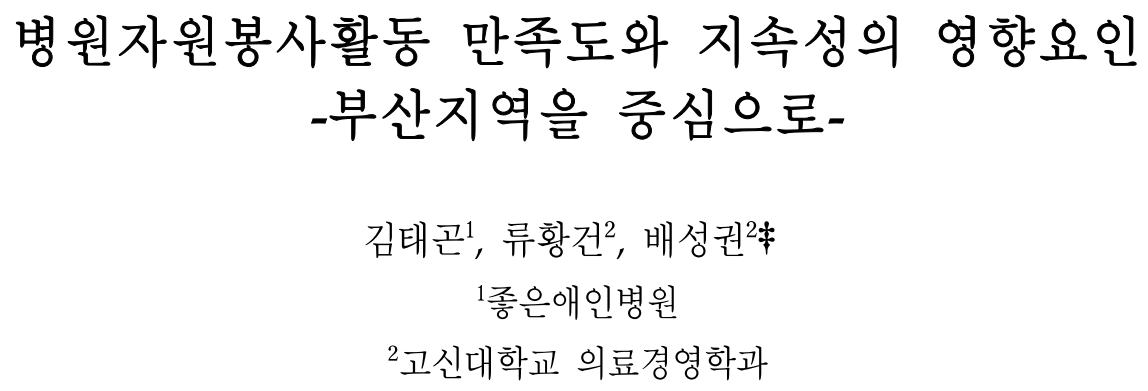

\title{
A Study on Influential Factors for the Continuance of Hospital Volunteer Activities
}

\author{
Tae-Gon Kim¹, Hwang-Gun Ryu ${ }^{2}$, Sung-Kwon Bae ${ }^{2 \ddagger}$ \\ ${ }^{1}$ Good Aein Hospital \\ ${ }^{2}$ Department of Health Sciences, Graduate School of Kosin University
}

\begin{abstract}
$<$ Abstract $>$
The aim of this study was to examine the impact of the participation motivation of hospital volunteers, their awareness of hospital image, hospital management of volunteers, the organizational interpersonal relationship of volunteers and their satisfaction with volunteer activities on the continuance of their volunteer activities.

The subjects were 480 volunteers who did volunteer activities in 37 hospitals in Busan, 399 subjects were responsed. This study is meaningful in that unlike relevant earlier studies of medicine, it attempted to make an integrative analysis of the influential factors for volunteer activities continuance and to make use of structural equation, a more advanced analysis technique. Besides, this study gave some suggestions on the customized management of hospital volunteers, its objects and related logical model.
\end{abstract}

Key Words : Hospital Volunteer Activities, Volunteer Activities Satisfaction, Volunteer Activities Continuance 


\section{I. 서론}

\section{1. 연구의 배경}

지역사회 복지를 강화하고 개선하기 위한 중요 한 방안 중에 하나로써 자원봉사활동의 중요성은 더욱 부각되고 있다. 특히, 이러한 봉사활동은 복 지사회를 이루는데 있어서의 필요한 요소로서 그 가치가 중요할 뿐 아니라, 바람직한 미래사회를 위 한 사회구성원의 기본적 책무로서도 그 의미가 부 각되고 있다. 이러한 자원봉사활동의 중요성이 높 아지면서, 자원봉사자의 수도 증가되고 있으며, 중. 고등학생에서부터 주부 그리고 노년층에 이르기까 지 다양한 계층에서 참여를 하고 있고, 활동영역도 교육, 지역사회개발, 보건·의료 등 등 광범위한 영 역에서 이루어지고 있다[1].

특히, 병원에서의 이루어지고 있는 자원봉사활 동은 인구구조의 고령화에 따른 만성퇴행성질환의 증가와 함께 의료이용량의 급속한 증가와 대응 의 료자원의 부족, 의료서비스 환경 변화 등으로 인하 여 그 중요성에 대한 인식이 점차적으로 확대되고 있다.

병원 자원봉사활동에 중요성이 더욱 커지고 있 는 이유를 분석해 보면, 첫째 사회적 문제의 해결 책으로써 자원봉사가 요구되고 있기 때문이다[2]. 만성퇴행성 질환의 증가와 정신적 스트레스의 증 가는 국민들의 건강에 많은 위협이 되고 있으며, 가족구조의 핵가족화는 지역사회가 노령인구에 대 한 수발을 보다 적극적으로 요구하게 되는 원인이 되고 있는 현 상황에서 자원봉사의 중요성은 점진 적으로 높아지고 있다.

둘째, 병원자원봉사는 의료자원이 수요에 비해 턱없이 부족한 현실에서 자원과 수요의 공백을 보 완해 주는 주요한 역할을 하고 있기 때문이다. 우 리 사회의 의료이용량이 기하급수적으로 증가하고 있고, 이에 반해 다양한 차원의 수요대응방안은 다
소 부족한 현실이다. 이러한 기하급수적으로 증가 하고 있는 의료수요에 대응하기 위한 일환으로 병 원자원봉사을 적극 고려해 볼 수 있다.

셋째, 대다수 사람들은 병원에 대한 다양한 정 보와 진료경험을 근거로 병원이미지를 형성하기 때문에 병원생존 전략의 하나로서 자원봉사활동이 요구되어진다. 의료서비스의 양적, 질적 확대와 그 로 인한 병원이미지의 향상, 병원경영의 합리화를 꾀하기 위하여 자원봉사의 필요성이 제기되고 있 다[3].

그러나 아직 우리나라의 병원자원봉사활동에 대 한 병원경영층의 인식도 부족하고 참여수준도 미 흡한 실정이다[4]. 병원자원봉사자들을 위한 프로 그램 준비 미흡과 담당직원의 의식 부족, 체계적인 관리부재로 인하여 자원봉사활동에 대한 만족도를 떨어뜨려 자원봉사자들이 지속적으로 자원봉사활 동을 전개해 나가는데 걸림돌로 작용하고 있다[5].

이에 본 연구는 부산지역에 소재하는 의료기관 의 자원봉사자들을 대상으로 병원자원봉사활동 지 속성에 영향을 미치는 요인을 파악하고 그 요인들 의 영향력은 어느 정도인지를 규명함으로써 봉사 자들이 병원자원봉사활동에 지속적으로 참여할 수 있는 개선 방안을 제시하고, 더 나아가 병원에서 병원자원봉사자들을 지속적으로 활용할 수 있는 과학적 관리방안과 활성화 방안을 제시하는 데 그 목적이 있다.

\section{ㅍ. 연구방법}

1. 연구대상 및 범위

부산지역 병원급 이상 243 곳의 의료기관 중에서 자원봉사활동이 수행되고 있는 71 개 의료기관 중 병원규모와 활동 중인 자원봉사자수를 고려하여 무작위로 대학병원 4 곳, 종합병원 10 곳, 병원 10 곳, 요양병원 13 곳 등 총 37 개 병원을 선정하여 병원 
자원봉사자들을 대상으로 설문조사를 실시하였다. 조사는 2011년 4월 16일부터 2011년 5월 21일까지 실시하였으며, 해당기관에 총 480 부의 설문지를 배 부하여 총 415 부를 회수하였다. 이 중 불성실한 응 답을 제외한 399부(83.1\%)를 최종 분석 자료로 활 용하였다.

\section{2. 조사분석 방법}

문헌고찰을 통하여 병원자원봉사활동 지속성에 대한 요인을 도출하였으며, 측정도구는 구조화된 설문을 선행연구를 통해 원용하고 연구자가 만든 문항을 추가하여 구성하였다. 수집된 자료는 SPSS 18.0 통계 패키지와 AMOS 7.0을 사용하여, 문항 간 일치도를 알기 위한 신뢰도 측정을 하여 Cronbach's $\alpha$ 값을 구하였으며, 측정문항의 타당성 을 검증하기 위해서 요인분석을 실시하였다. 각 변 인들의 상관관계를 알아보기 위하여 상관분석을 하였으며, 변수들 간의 인과관계를 분석하기 위하 여 구조방정식 모델 (Structural Equation Modeling:SEM)을 통한 경로분석을 하였다.
병원자원봉사활동의 지속성 영향요인에 관한 연 구로 자원봉사기관의 특성(병원이미지 인식 요인, 자원봉사자 관리 요인, 조직 내 대인관계 요인)의 측면에서 실증 분석하고 이러한 결과를 기초로 효 과적인 병원자원봉사활동 관리방안을 모색하고자 한다. 본 연구의 과정을 도식화 하면 다음의 <그 림 $1>$ 과 같다.

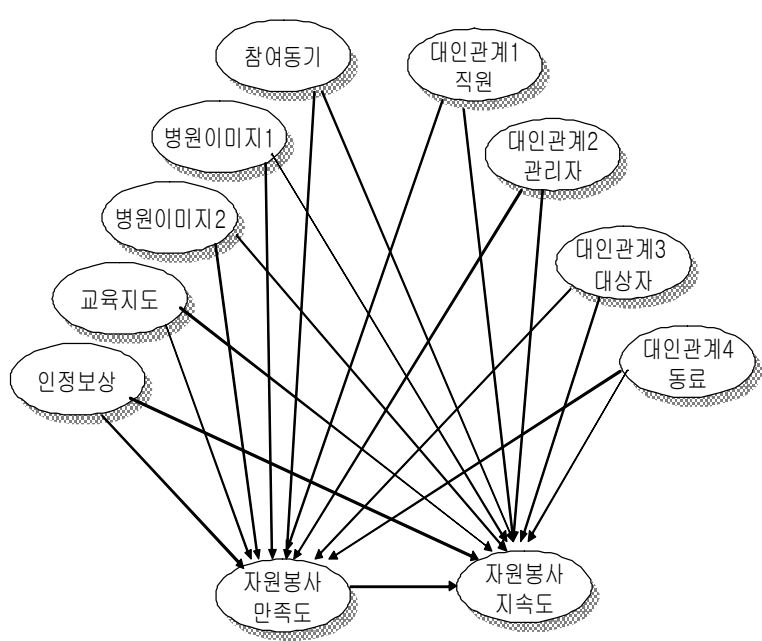

<그림 1> 연구의 개념적 모형 및 과정

3. 연구모형

<표 1> 설문문항의 출처 및 구성

\begin{tabular}{|c|c|c|c|}
\hline 설문항목 & 설문문항 출처 & 요인 또는 변수 & 문항수 \\
\hline 인구사회학적 요인 & 연구자 작성 & 성별, 연령, 결혼상태, 학력, 직업, 종교 & 6 \\
\hline 참여동기 & 남문현(2008) & 이타적 요인, 이기적 요인 & 10 \\
\hline 병원이미지 인식 & $\begin{array}{l}\text { 강경희(2006) } \\
\text { 김미녀(2009) } \\
\text { 연구자 }\end{array}$ & $\begin{array}{l}\text { 병원의 특성 인지 여부 } \\
\text { 명성, 평판, 신뢰도, 애호도 }\end{array}$ & 14 \\
\hline 자원봉사자 관리 & $\begin{array}{l}\text { 오효근(2007) } \\
\text { 연구자 }\end{array}$ & 교육, 지도관리, 인정보상 & 17 \\
\hline 조직내 대인관계 & $\begin{array}{l}\text { 김숙경(2001) } \\
\text { 오효근(2007) }\end{array}$ & $\begin{array}{l}\text { 직원과의 관계/ 관리(담당)자와의 관계 } \\
\text { 대상자와의 관계/동료봉사자와의 관계 }\end{array}$ & 18 \\
\hline 봉사활동 만족도 & 오효근(2007) & 활동 만족도 & 7 \\
\hline $\begin{array}{l}\text { 봉사활동 } \\
\text { 지속성 }\end{array}$ & $\begin{array}{l}\text { 박진호(1998) } \\
\text { 김정애(2005) } \\
\text { 남문현(2008) }\end{array}$ & $\begin{array}{l}\text { 지속참여 의지 } \\
\text { 참여경로, 봉사환동업무, } \\
\text { 봉사경력, 봉사량, } 1 \text { 회 봉사시간 }\end{array}$ & 6 \\
\hline
\end{tabular}


설문내용은 7개의 범주로 나누어 인구사회학적, 참여동기[6], 병원이미지 인식[7][8], 자원봉사자 관 리[9], 조직 내 대인관계[9][10], 봉사활동만족도[9], 봉사활동지속성[11][12][6] 등 총 78 문항으로 구성 되어 있다. 설문의 척도는 병원이미지 인식정도, 자원봉사자 관리과정의 일부 문항과, 자원봉사활동 실태, 인구사회학적 특성을 제외한 모든 항목은 리 커트식 5점 척도를 사용하였다<표 1>.

\section{4. 가설 설정}

본 연구의 목적을 달성하기 위해 본 연구의 개념적 모형에서 논의한 병원자원봉사활동 지속성 영향요인에 대한 이론적 고찰을 토대로 다음과 같 이 본 연구에서 일반적 특성, 자원봉사기관 특성, 자원봉사활동 만족도 등의 변이를 사용하여 가설 을 설정하였다.

가설 1. 병원자원봉사자의 참여동기가 강할수록 자원봉사활동 만족도가 높을 것이다.

가설 2. 병원자원봉사자의 참여동기가 강할수록 자원봉사활동 지속성이 높을 것이다.

가설 3. 자원봉사기관의 특성은 자원봉사활동 만족도에 영향을 줄 것이다.

가설 4. 자원봉사기관의 특성은 자원봉사활동 지속성에 영향을 줄 것이다.

가설 5. 자원봉사자의 활동만족도가 높을수록 자원봉사활동 지속성이 높을 것이다.

\section{III. 연구결과}

\section{1. 연구대상자의 일반적 특성}

조사대상자의 인구사회학적 특성인 성별, 연령, 결혼상태, 학력, 직업, 종교를 살펴본 결과는 다음 의 <표 2>와 같다. 성별은 '여자' 333 명 $(83.5 \%)$, '남
자'66명 $(16.5 \%)$ 으로 여자가 많았고, 연령을 최고 77 세에서 최소 17 세에 걸쳐 분포되어 있으며, 평균 연령은 44세로 나타났고, 연령별 분포는 50 59세 가 $26.6 \%$ 로 가장 높은 비중을 차지하였다. 결혼 상 태에 따른 연구대상자의 인구사회학적 특성은 기 혼이 $64.7 \%$, 미혼이 $35.3 \%$ 로 기혼자가 상대적으로 2 배 가까이 더 많았다. 학력은 고졸 $46.4 \%$ 과 대졸 이상 $43.7 \%$ 이 대부분을 차지하였으며, 중졸이하가 $10.0 \%$ 였다. 직업은 주부가 $49.1 \%$ 로 가장 많았으며, 종교는 불교가 $33.3 \%$ 무교 $26.8 \%$, 기독교 $18.8 \%$, 천주교 $17.3 \%$, 기타 $3.8 \%$ 순이었고, 종교를 가진 사람이 전체 $69.4 \%$ 로 분석되었다.

<표 2> 연구대상자의 인구사회학적 특성

\begin{tabular}{|c|c|c|c|}
\hline \multicolumn{2}{|c|}{ 구 분 } & 빈도 & $\%$ \\
\hline \multirow[t]{2}{*}{ 성별 } & 남자 & 66 & 16.5 \\
\hline & 여자 & 333 & 83.5 \\
\hline \multirow[t]{7}{*}{ 연령 } & 10 19세 & 29 & 7.3 \\
\hline & 20 29세 & 90 & 22.6 \\
\hline & 30 39세 & 29 & 7.3 \\
\hline & 40 49세 & 50 & 12.5 \\
\hline & 50 59세 & 106 & 26.6 \\
\hline & 60 69세 & 76 & 19.0 \\
\hline & 70세 이상 & 19 & 4.8 \\
\hline \multicolumn{2}{|c|}{ 연령(평균土표준편차) } & & $44.28 \pm 17.2$ \\
\hline 결혼 & 기혼 & 258 & 64.7 \\
\hline 상태 & 미혼 & 141 & 35.3 \\
\hline \multirow[t]{3}{*}{ 학력 } & 중졸 이하 & 40 & 10.0 \\
\hline & 고졸 & 185 & 46.4 \\
\hline & 대졸 이상 & 174 & 43.7 \\
\hline \multirow[t]{7}{*}{ 직업 } & 회사원 & 25 & 6.3 \\
\hline & 자영업 & 15 & 3.8 \\
\hline & 주부 & 196 & 49.1 \\
\hline & 학생 & 101 & 25.3 \\
\hline & 전문직 & 17 & 4.3 \\
\hline & 무직 & 21 & 5.3 \\
\hline & 기타 & 24 & 6.0 \\
\hline \multirow[t]{6}{*}{ 종교 } & 무교 & 107 & 26.8 \\
\hline & 기독교 & 75 & 18.8 \\
\hline & 천주교 & 69 & 17.3 \\
\hline & 불교 & 133 & 33.3 \\
\hline & 기타 & 15 & 3.8 \\
\hline & 계 & 399 & 100.0 \\
\hline
\end{tabular}


<표 3> 지원봉사활동 관련 주요 설문문항의 신뢰도 검증

\begin{tabular}{|c|c|c|c|c|c|}
\hline 요인 & & 설문내용 & 평균 & 표준편차 & Cronbach 알파 \\
\hline \multirow{3}{*}{$\begin{array}{l}\text { 참여동기 } \\
\text { (3) }\end{array}$} & & 사회발전 기여 & 3.49 & 9.92 & \multirow{3}{*}{.727} \\
\hline & & 대인관계 확대 & 3.13 & 1.01 & \\
\hline & & 지역사회 좋은 미래 조성 & 3.64 & .92 & \\
\hline \multirow{9}{*}{$\begin{array}{l}\text { 병원이미지 } \\
\text { 인식(9) }\end{array}$} & \multirow{2}{*}{ 병원이미지1- } & 사회적 명성 & 3.78 & .71 & \multirow{9}{*}{.906} \\
\hline & & 의술 신뢰감 & 3.74 & .67 & \\
\hline & \multirow{7}{*}{$\begin{array}{l}\text { 병원 이미지2 } \\
\text { 서비스경영 }\end{array}$} & 직원서비스 신뢰감 & 3.81 & .74 & \\
\hline & & 서비스 개발 노력 & 3.85 & .68 & \\
\hline & & 지역사회 발전기여 & 3.83 & .70 & \\
\hline & & 환자를 위한 경영실천 & 3.79 & .72 & \\
\hline & & 병원에 대한 친밀감 & 3.91 & .73 & \\
\hline & & 병원 발전가능성 & 3.96 & .69 & \\
\hline & & 의료서비스에 대한 호의적 태도 & 3.75 & .72 & \\
\hline \multirow{11}{*}{$\begin{array}{l}\text { 자원봉사자 } \\
\text { 관리(11) }\end{array}$} & \multirow{6}{*}{$\begin{array}{l}\text { 교육 지도 관 } \\
\text { 리 }\end{array}$} & 지속적 실시 & 3.79 & .73 & \multirow{11}{*}{.920} \\
\hline & & 봉사활동에 유익함 & 4.02 & .63 & \\
\hline & & 교육의 적절성 & 3.85 & .69 & \\
\hline & & 관리자의 적절한 지도관리 & 3.96 & .71 & \\
\hline & & 지도관리의 적절성 & 3.89 & .67 & \\
\hline & & 지도관리의 유익함 & 3.93 & .67 & \\
\hline & \multirow{5}{*}{ 인정과 보상 } & 적절한 인정과 보상 & 3.69 & .84 & \\
\hline & & 인정과 보상에 대한 만족 & 3.61 & .83 & \\
\hline & & 성장기회 제공 & 3.69 & .82 & \\
\hline & & 관리자로부터 정신적 보상 & 3.69 & .80 & \\
\hline & & 대상자로부터 정신적 보상 & 3.66 & .81 & \\
\hline \multirow{17}{*}{$\begin{array}{l}\text { 봉사활동 } \\
\text { 조직 내 } \\
\text { 대인관계 } \\
\text { (17) }\end{array}$} & \multirow{3}{*}{ 직원관계 } & 병원직원과의 업무관계 만족 & 3.75 & .72 & \multirow{17}{*}{.931} \\
\hline & & 병원직원과의 정서적 관계 만족 & 3.73 & .75 & \\
\hline & & 직원의 태도만족 & 3.80 & .78 & \\
\hline & \multirow{5}{*}{ 관리자관계 } & 관리자의 관심 & 3.91 & .70 & \\
\hline & & 관리자의 적절한 지도와 평가 & 3.88 & .76 & \\
\hline & & 관리자의 대우 & 3.89 & .73 & \\
\hline & & 관리자의 제안수용 & 3.84 & .78 & \\
\hline & & 관리자의 인정과 격려 & 3.93 & .74 & \\
\hline & \multirow{4}{*}{ 대상자관계 } & 시간할애 & 3.89 & .70 & \\
\hline & & 대상자의 긍정적 변화 & 3.75 & .68 & \\
\hline & & 대상자의 협조 & 3.86 & .69 & \\
\hline & & 대상자의 관계유지 & 3.70 & .78 & \\
\hline & \multirow{5}{*}{ 동료관계 } & 동료봉사자와의 관계 & 4.03 & .69 & \\
\hline & & 동료와의 시간 & 4.08 & .68 & \\
\hline & & 동료와 상호 협력 & 4.00 & .71 & \\
\hline & & 동료간의 지지 & 3.83 & .76 & \\
\hline & & 동료간의 의견충돌 부재 & 4.03 & .73 & \\
\hline \multirow{6}{*}{\multicolumn{2}{|c|}{ 봉사활동 만족도(6) }} & 전반적 자원봉사 만족도 & 4.10 & .60 & \multirow{6}{*}{.873} \\
\hline & & 봉사활동에 대한 인식 & 4.06 & .61 & \\
\hline & & 봉사활동의 적합성 & 3.99 & .64 & \\
\hline & & 봉사활동의 보람 & 4.17 & .60 & \\
\hline & & 봉사활동의 능력발휘 & 3.77 & .77 & \\
\hline & & 봉사활동을 통한 자기계발 & 3.99 & .72 & \\
\hline
\end{tabular}


2. 자원봉사활동 영향요인 분석과 신뢰도 분석

설문에서 사용된 주요변수의 특성과 설문의 주 요항목별 신뢰도 값은 <표 3>과 같다. 본 연구에 서는 신뢰도를 측정하기 위하여 내적일관성 (internal consistency reliability)을 고려하는 Cronbach's $\alpha$ 계수를 이용하였으며, Cronbach's $\alpha$ 값이 .70 이상인 항목만 선택하여 본 연구를 위한 최종 문항으로 하였다.

<표 4> 자원봉사활동 관련 주요 설문 항목의 요인분석

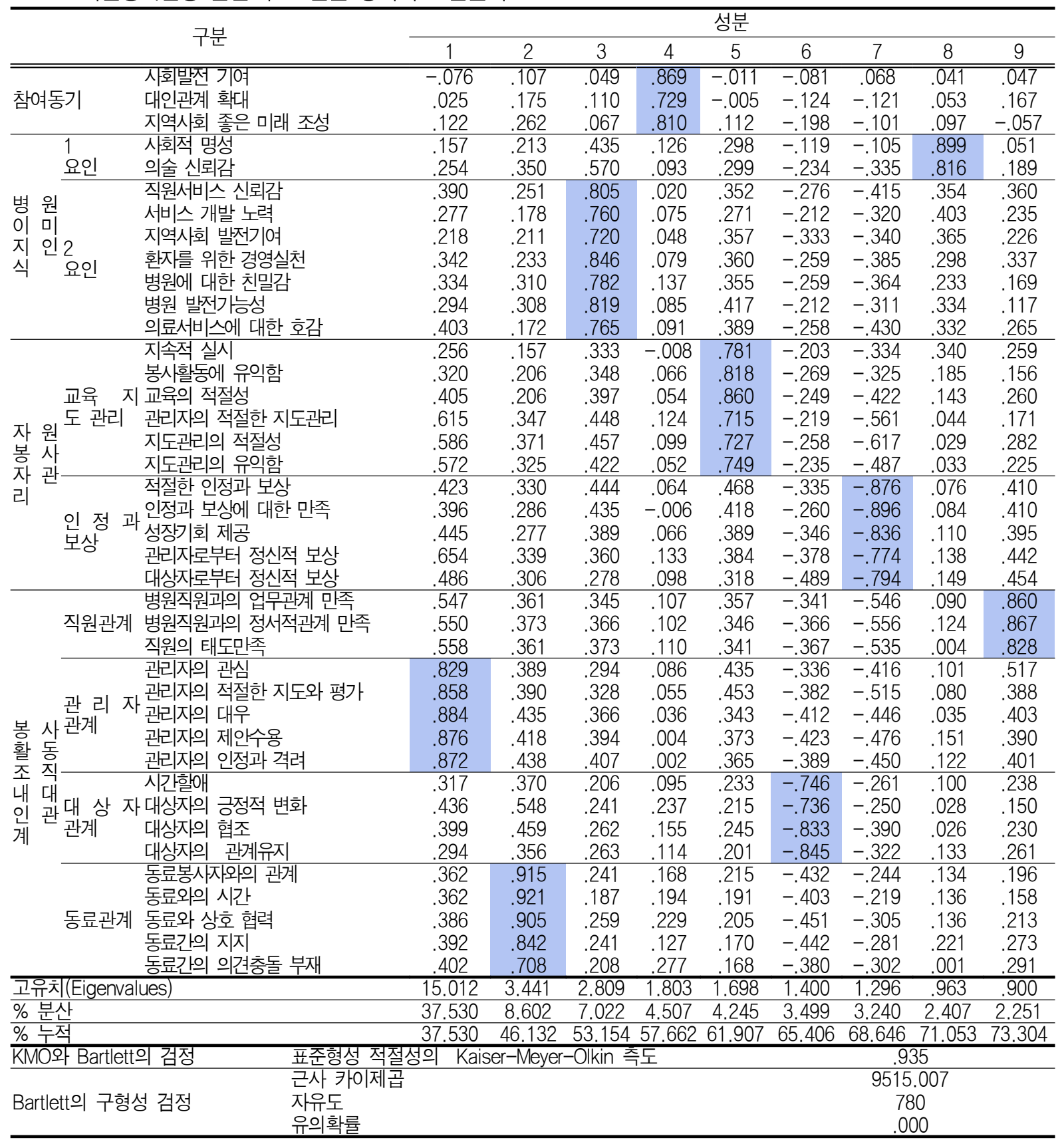


본 연구의 신뢰도는 Cronbach's $\alpha$ 값이 참여동 기는 .727이었고, 병원이미지 인식 .906, 자원봉사 자 관리 .920 , 조직 내 대인관계 .931 그리고 봉사 활동 만족도는 .873이었다<표 3>.

3. 측정도구의 타당도 분석
연구 측정도구에 대한 타당성을 검증하기 위해 직접 오블리민(Direct Oblimin)방법의 사각회전 요 인분석을 실시하였다. 요인분석 결과 $\mathrm{KMO}$ 값이 일 반적으로 0.9 이상이면 적합한 모델로 평가하는데 0.935로서 요인분석이 통계적으로 유의하였으며, 9 개의 요인으로 추출되었다<표 4>.

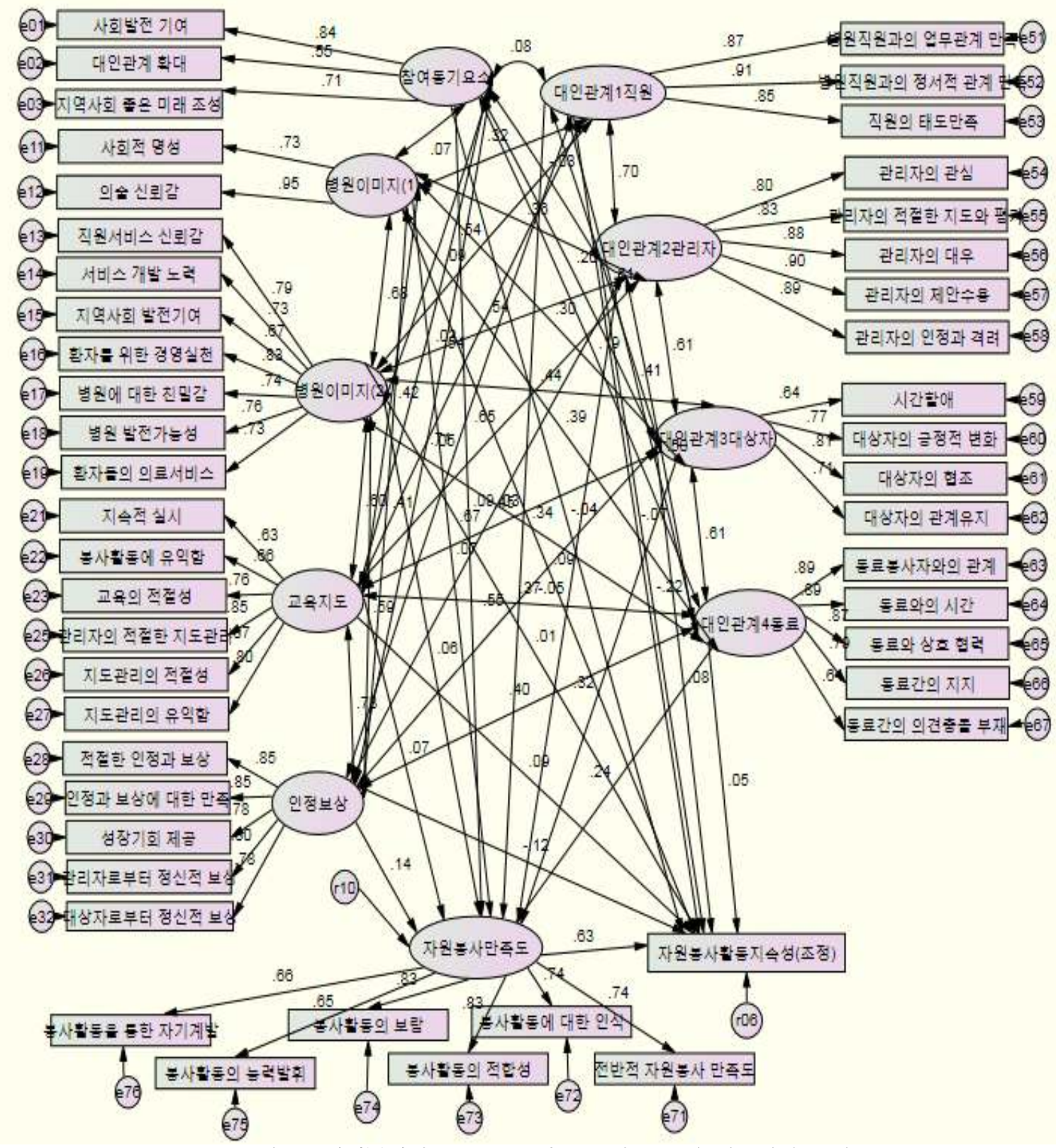

<그림 2> 자원봉사활동 주요 요인을 중심으로 한 경로회귀 모형 
3. 연구모형의 경로회귀 분석

본 연구모형의 적합도는 $X^{2}=1970.733(\mathrm{df}=980)$, $\mathrm{p}=.000$ 였으며, TLI= .909, GFI=.921, RMSEA $=.050$ 으로 나타나 최적 모형의 적합수준에 가까운 수치 를 나타내고 있어 모형이 적합한 것으로 분석되었 다 본 연구의 자원봉사활동 주요 요인을 중심으 로 한 경로회귀모형에 대한 경로분석 결과는 <그 림 2>와 같다.

\section{4. 연구가설의 검정}

병원자원봉사활동의 참여동기, 병원이미지 인식, 자원봉사자관리, 조직 내 대인관계, 자원봉사 만족 도가 병원자원봉사활동의 지속성에 영향을 주는 요인을 분석한 결과는 다음과 같다<표 5>.

가설 1 과 가설 2 인 '병원자원봉사자의 참여동기
가 강할수록 자원봉사활동 만족도와 지속도가 높 을 것이다'는 것은 기각되었다. 가설 3 '자원봉사기 관의 특성은 자원봉사활동 만족도에 영향을 줄 것 이다'은 일부만 채택되었다. 자원봉사기관의 특성 인 조직 내 대인관계의 세부요소 중 대상자와의 관계와 동료 간의 관계만 통계적으로 유의한 것으 로 분석되어 일부만 채택되었다. 가설 4 '자원봉사 기관의 특성은 자원봉사활동 지속성에 영향을 줄 것이다'도 일부만 채택되었다. 자원봉사기관의 특 성인 관리자에 의해 자원봉사활동 지속성이 영향 을 미치고 있었다. 가설 5 '자원봉사자의 활동만족 도가 높을수록 자원봉사활동 지속성이 높을 것이 다.'는 채택되었다. 즉 표준화계수 .632로 정(+)의 영향을 미치고 있으며, $\mathrm{CR}(\mathrm{t}$ 값) 8.711에 대한 유의 확률 $\mathrm{p}$ 값이 .000 으로 통계적으로 유의한 차이가 있었다.

<표 5> 가설검증 결과

\begin{tabular}{|c|c|c|c|c|c|c|c|c|}
\hline \multirow{2}{*}{ 구분 } & & & \multicolumn{2}{|c|}{ 경로회귀계수 } & \multirow{2}{*}{ S.E. } & \multirow{2}{*}{ C.R. } & \multirow{2}{*}{$P$} & \multirow{2}{*}{$\begin{array}{l}\text { 채택 } \\
\text { 여부 }\end{array}$} \\
\hline & & & 비표준화 & 표준화 & & & & \\
\hline \multirow[t]{9}{*}{ 자원봉사만족도 } & ↔ & 참여동기요소 & 0.052 & 0.09 & 0.029 & 1.804 & 0.071 & 기각 \\
\hline & $\diamond$ & 병원이미지(1) & 0.064 & 0.075 & 0.057 & 1.123 & 0.261 & 기각 \\
\hline & $\diamond$ & 병원이미지(2) & 0.042 & 0.055 & 0.06 & 0.696 & 0.487 & 기각 \\
\hline & $\diamond$ & 교육지도 & 0.068 & 0.071 & 0.074 & 0.923 & 0.356 & 기각 \\
\hline & $\diamond$ & 인정과 보상 & 0.083 & 0.135 & 0.054 & 1.534 & 0.125 & 기각 \\
\hline & $\diamond$ & 대인관계1직원 & 0.023 & 0.033 & 0.054 & 0.434 & 0.664 & 기각 \\
\hline & $\diamond$ & 대인관계2관리자 & -0.038 & -0.047 & 0.064 & -0.584 & 0.559 & 기각 \\
\hline & $\diamond$ & 대인관계3대상자 & 0.321 & 0.324 & 0.077 & 4.169 & $\star \star \star ~$ & 채택 \\
\hline & $\diamond$ & 대인관계4동료 & 0.172 & 0.235 & 0.045 & 3.787 & $\star \star \star *$ & 채택 \\
\hline \multirow[t]{10}{*}{ 자원봉사지속성 } & $\diamond$ & 참여동기요소 & -0.034 & -0.043 & 0.04 & -0.847 & 0.397 & 기각 \\
\hline & $\diamond$ & 병원이미지(1) & 0.11 & 0.094 & 0.079 & 1.39 & 0.165 & 기각 \\
\hline & $\diamond$ & 병원이미지(2) & 0.01 & 0.01 & 0.083 & 0.118 & 0.906 & 기각 \\
\hline & $\diamond$ & 교육지도 & 0.117 & 0.09 & 0.103 & 1.143 & 0.253 & 기각 \\
\hline & $\diamond$ & 인정과 보상 & -0.102 & -0.121 & 0.075 & -1.35 & 0.177 & 기각 \\
\hline & $\diamond$ & 대인관계1직원 & -0.07 & -0.073 & 0.074 & -0.95 & 0.342 & 기각 \\
\hline & $\diamond$ & 대인관계2관리자 & -0.234 & -0.217 & 0.09 & -2.614 & 0.009 & 채택 \\
\hline & ه & 대인관계3대상자 & 0.108 & 0.08 & 0.107 & 1.005 & 0.315 & 기각 \\
\hline & $\diamond$ & 대인관계4동료 & 0.047 & 0.047 & 0.063 & 0.741 & 0.459 & 기각 \\
\hline & $\diamond$ & 자원봉사만족도 & 0.862 & 0.632 & 0.099 & 8.711 & $\star \star \star$ & 채택 \\
\hline 모형 적합도 & & $\begin{array}{l}x^{2}=1970.733 \\
d f=980\end{array}$ & \multicolumn{2}{|c|}{$\begin{array}{l}p=0.000 \\
T L I=0.909\end{array}$} & \multicolumn{4}{|c|}{$\begin{array}{l}\text { GFI }=0.921 \\
\text { RMSEA }=0.050\end{array}$} \\
\hline
\end{tabular}


<표 6> 봉사활동 만족도와 지속성에 대한 요인들의 직.간접효과 및 총 효과

\begin{tabular}{|c|c|c|c|c|c|}
\hline 내생변수 & & 외생변수 & 총영향 & 직접 & 간접 \\
\hline \multirow[t]{9}{*}{ 자원봉사만족도 } & 它 & 참여동기요소 & 0.090 & 0.090 & 0 \\
\hline & $\diamond$ & 병원이미지(1) & 0.075 & 0.075 & 0 \\
\hline & $\diamond$ & 병원이미지(2) & 0.055 & 0.055 & 0 \\
\hline & $\diamond$ & 교육지도 & 0.071 & 0.071 & 0 \\
\hline & $\diamond$ & 인정과 보상 & 0.135 & 0.135 & 0 \\
\hline & $\diamond$ & 대인관계1직원 & 0.033 & 0.033 & 0 \\
\hline & ڤ & 대인관계2관리자 & -0.047 & -0.047 & 0 \\
\hline & $\diamond$ & 대인관계3대상자 & 0.324 & 0.324 & 0 \\
\hline & $\diamond$ & 대인관계4동료 & 0.235 & 0.235 & 0 \\
\hline \multirow[t]{10}{*}{ 자원봉사지속성 } & 它 & 참여동기요소 & 0.014 & -0.043 & 0.057 \\
\hline & $\diamond$ & 병원이미지(1) & 0.141 & 0.094 & 0.047 \\
\hline & $\diamond$ & 병원이미지(2) & 0.044 & 0.010 & 0.035 \\
\hline & ڤ & 교육지도 & 0.135 & 0.090 & 0.045 \\
\hline & $\diamond$ & 인정과 보상 & -0.036 & -0.121 & 0.085 \\
\hline & $\diamond$ & 대인관계1직원 & -0.052 & -0.073 & 0.021 \\
\hline & $\diamond$ & 대인관계2관리자 & -0.247 & -0.217 & -0.030 \\
\hline & $\diamond$ & 대인관계3대상자 & 0.285 & 0.080 & 0.205 \\
\hline & $\diamond$ & 대인관계4동료 & 0.196 & 0.047 & 0.149 \\
\hline & $\diamond$ & 자원봉사만족도 & 0.632 & 0.632 & 0 \\
\hline
\end{tabular}

* : 영향력이 유의한 경우

5. 변수들의 직접효과 및 간접효과

봉사활동 만족도와 지속성에 대한 요인들의 직. 간접효과 및 총 효과를 보면 <표 6>과 같다.

본 연구의 경로 추정치에서 봉사활동 만족도에 가장 큰 효과를 미치는 요인은 대인관계3대상자 0.324 , 대인관계 4 동료 0.235 였다. 봉사활동 지속성 에 가장 큰 효과를 미치는 변인은 자원봉사만족도 0.632 였다.

지속성에 대한 총 효과가 가장 높은 것은 대인 관계3대상자 요인으로 0.285 로 조사되었고, 간접효 과가 0.205 로서 직접적인 효과보다 더 높았다. 다 음은 대인관계2관리자로 총 효과는 -0.247 , 직접효 과는 -0.217 , 간접효과는 -0.03 로 분석되었다. 또한, 대인관계 4 동료 요인도 총 효과 0.196 , 직접효과 0.047 , 간접효과 0.149 로 조사되어 간접효과가 더 큰 것으로 분석되었다.

봉사활동 지속성에 대한 변인들의 효과를 요약
하면 봉사활동지속성에 자원봉사만족도가 큰 효과 를 보였고, 자원봉사만족도에는 대인관계3대상자, 대인관계 4 동료가 가장 큰 효과를 보였다. 그러므로 병원자원봉사자가 조직 내 봉사대상자와 봉사활동 동료와의 관계가 좋을수록 봉사만족도가 높아지며, 봉사활동 만족도가 높을수록 봉사활동 지속성이 높아지는 것을 알 수 있다. 따라서 봉사활동 만족 도가 매개변인으로서 조절효과로 작용한다고 할 수 있다.

$$
\text { IV. 고찰 }
$$

본 연구의 가설 검증 결과에서 봉사활동 만족도 와 봉사활동 지속성에 미치는 영향관계를 분석한 결과 참여동기와 봉사활동 만족도 및 지속성과의 관계에 있어서는 본 연구 결과에서 병원자원봉사 자의 참여동기는 이타적 동기가 이기적 동기보다 앞서는 것을 알 수 있었으나, 참여동기가 봉사활동 
만족도나 지속성에 영향을 미치지 않는 것으로 나 타났다. 이는 조영아(2005)[13], 오효근(2007)[9]의 연구에서 참여동기가 강하면 자원봉사 만족도가 높고 자원봉사 지속성의 효과가 있는 것으로 나타 난 것과는 일치하지 않는다. 반면에 안소윤 (2007)[2]의 연구에서 활동만족도에 유의미한 영향 이 없는 것으로 나타난 결과와는 일치하였다.

병원에 대한 이미지 인식정도와 봉사활동 만족 도 및 지속성과의 관계에 있어서 병원의 명성에 대한 인식과 병원의 발전가능성에 대한 긍정적인 답이 높게 나왔으나 병원에 대한 이미지인식 정도 가 봉사활동 만족도나 지속성에 영향을 미치지 않 는 것으로 나타났다. 이는 정명숙(1999)[14]의 연구 에서 차별적 영향을 받는 것으로 나타난 것과는 일치하지 않는다. 하지만 김미녀(2009)[8]의 연구에 서 직접적인 영향을 나타내지 못한 결과와는 동일 함을 알 수 있다.

자원봉사자 관리수준과 봉사활동 만족도 및 지 속성과의 관계에 있어서본 연구 결과에서 자원봉 사자 관리과정에서 교육은 활동에 도움이 되고 관 리(담당)자의 지도관리가 잘 이루어지고 있다고 하 지만 지속적인 교육과 봉사활동 특성에 맞는 적절 한 교육이 이루어져야 하며, 인정보상에 각별한 관 심이 요구되는 것으로 나타났다. 하지만 자원봉사 활동 관리수준이 봉사자들의 봉사활동 만족도나 지속성을 높이지 않는다는 것으로 분석되었다. 이 는 김숙경(2001)[10]의 연구에서 지속성에 영향을 미친다는 결과와 오효근(2007)[9]의 연구에서 지속 성에는 직접적 영향을 미치고 만족도에는 영향을 미치지 않는 것으로 나타난 결과와 일치하지 않음 을 알 수 있다.

대인관계와 봉사활동 만족도 및 지속성과의 관 계에 있어서는 본 연구 결과에서 대인관계는 자원 봉사 만족도를 통해서 지속성에 효과를 일부 요소 에서 영향을 미치는 것으로 나타났다. 또한 매개경 로 유의미성 검증결과 대인관계는 부분 매개의 효
과로 지속성으로 가는 경로의 설명력이 가장 높게 나타났다. 즉 병원자원봉사자들의 자원봉사활동은 대인관계가 지속성에 미치는 영향력이 가장 높음 을 알 수 있었다. 이는 대인관계가 만족도에 긍정 적인 영향을 미친다고 보고한 권지성(1999)[15], 한 수정(1999)[16], 오효근(2006)[9], 승금희(2008)[5]의 연구와 일치하며, 대인관계가 지속성에 직접적으로 영향을 미치는 Gidron(1984)[17], 김숙경(2001)[10], 이성록(2001)[18], 이병순(2004)[19]의 연구 결과와 도 일치하고 있다. 병원자원봉사자들의 활동 대상 자와의 관계, 동료 자원봉사자와의 관계가 긍정적 일수록 자원봉사 만족과 지속성의 효과가 있는 것 을 알 수 있었다. 결론적으로 자원봉사활동에 대한 보다 적극적인 관심과 배려는 병원을 이용하는 의 료소비자에게도 중요한 영향을 줄 것으로 판단된 다. 병원에 있어서 환자의 신뢰도와 만족도를 높이 는 데[20] 있어서 보다 넓은 차원에서의 자원봉사 활동도 고려되어야 한다고 사려된다.

\section{$\mathrm{V}$. 결론}

본 연구는 병원자원봉사활동 지속성에 영향을 미치는 요인을 파악하고 그 요인들의 영향력은 어 느 정도인지를 규명함으로써 봉사자들이 병원자원 봉사활동에 지속적으로 참여할 수 있는 방안을 제 시하고자 시도되었다. 자원봉사활동 지속성에 미치 는 영향요인을 설명하는 가설적 모형에 포함된 변 수는 외생변수로 참여동기, 병원이미지 인식, 자원 봉사자 관리, 조직 내 대인관계이며, 내생변수는 자원봉사활동 만족도와 자원봉사활동 지속성이었 다.

자원봉사활동 지속성에 대한 요인들의 효과에 대한 연구결과를 요약하면, 자원봉사활동 지속성에 자원봉사활동 만족도가 가장 큰 효과를 보였고, 자 원봉사만족도에는 자원봉사 대상자와의 관계와 자 
원봉사자 동료 간의 관계가 가장 큰 효과를 보였 다. 그러므로 병원자원봉사자가 자원봉사대상자와 봉사활동 동료와의 관계가 좋을수록 봉사만족도가 높아지며, 봉사활동 만족도가 높을수록 봉사활동 지속성이 높아지는 것을 알 수 있었다. 그리고 봉 사활동 만족도가 매개변인으로서 조절효과로 작용 하는 것을 확인 할 수 있었다.

본 연구는 병원자원봉사활동의 지속성에 영향을 주는 요인을 설명할 수 있는 이론적 모형을 개발 함으로써, 병원자원봉사 활동 지속성의 설명력을 한 단계 향상 시켰다고 본다. 본 연구 이전에도 사 회복지분야의 연구에서는 유사한 이론적 모형을 통한 연구가 있었으나, 의료분야에서는 선례가 없 으며 지속성에 대한 연구는 시도되지 않았다. 본 연구에서는 병원자원봉사자들의 자원봉사활동 지 속성에 영향을 주는 개념 간 관계를 모형화 함으 로써 선행연구들에서 자원봉사 만족도 분석에 그 쳤던 변인들을 지속성을 중심으로 다양한 관계를 연결하여 병원자원봉사 지속성 요인에 대한 입체 적인 과정의 설명을 제시하였다.

본 연구에서는 자원봉사활동 지속성을 더 체계 적으로 설명하기 위하여 자원봉사활동 만족도라는 개념을 상호연계하여 제시하였는데, 자원봉사활동 을 구성하는 요인들에 대해서는 보다 심도있는 연 구가 향후 요구된다고 보여진다. 연구결과, 병원자 원봉사 활동에 있어서 봉사 대상자와 봉사자동료 간 대인관계가 자원봉사 만족도를 통해 지속성에 영향을 미치고 있음을 알 수 있었다. 이는 병원자 원봉사자들의 지속적인 자원봉사활동이 되기 위해 서는 대인관계 관련 세부요인을 실천현장에서 명 확하게 파악하고 지지함으로써 자원봉사활동 만족 도를 충족시켜 자원봉사의 지속성을 높여야 한다 는 것을 시사하고 있다. 병원에서는 대인관계의 중 요성을 인식하고 유기적이고 원활한 관계가 형성 될 수 있는 환경조성에 힘쓰고 대인관계 접점관리 를 통하여 참여하는 자원봉사자들의 기대를 충족
시킬 수 있도록 하여야 할 것이다.

\section{참고문헌}

1. 이성록(2005), 자원봉사 어드바이저, 미디어숲, pp.15-60.

2. 안소윤(2007), 병원자원봉사활동의 만족도에 영향 을 미치는 요인에 관한 연구, 대구대학교 사회복 지대학원 석사학위논문, pp.9-15, 36-71.

3. 이명섭(2009), 대학병원 자원봉사자들의 자원봉사 활동 만족도에 관한 연구, 영남대학교 행정대학원 석사학위논문, pp.24-30.

4. 최진순(2002), 병원자원봉사활동에 대한 자원봉사 만족도 및 만족요인에 관한 연구, 대구대학교 대 학원 박사학위논문, pp.10-22.

5. 승금희(2008), 자원봉사활동 만족도에 영향을 미치 는 요인에 관한 연구, 서울기독대학교 대학원 박 사학위논문, pp.88-101.

6. 남문현(2008), 복지목회를 위한 자원봉사 참여지속 성에 관한 연구, 한영신학대학교 대학원. 박사학위 논문, pp.56-60.

7. 강경희(2006), 의료서비스 품질이 환자만족과 병원 이미지, 고객충성도에 미치는 영향에 관한 연구, 제주대학교 대학원 석사학위논문, pp.10-62.

8. 김미녀(2009), 의료서비스에서 환자만족의 선·후행 변수 관계에 관한 연구, 경상대학교 대학원 박사 학위논문, pp.24-57, 124-136.

9. 오효근(2007), 대학생 자원봉사활동의 지속성에 영 향을 미치는 요인에 관한 연구, 경기대학교 대학 원 박사학위논문, pp.13-56.

10. 김숙경(2001), 사회복지분야 자원봉사자의 지속적 활동에 영향을 미치는 요인에 관한 연구, 대구대 학교 대학원 박사학위논문, pp.15-106.

11. 박진호(1998), 자원봉사자의 재참여 의사결정모형 에 관한 연구, 대구대학교 대학원 박사학위논문, pp.77-93. 
12. 김정애(2005), 병원자원봉사 활성화 방안에 관한 연구, 명지대학교 대학원 석사학위논문, pp.24-51.

13. 조영아(2005), 컨벤션 자원봉사자의 참여동기와 셀프리더십이 활동만족요인에 미치는 영향, 경기 대학교 대학원 박사학위논문, pp.55-102.

14. 정명숙(1999), 병원이미지가 병원재선택에 미치는 영향에 관한 연구, 전남대학교 경영대학원 석사학 위논문, pp.28-44.

15. 권지성(1999), 자원봉사 참여형태에 따른 대학생 자원봉사활동의 만족도, 서울대학교 대학원 석사 학위논문, pp.34-56.

16. 한수정(1999), 대학생 자원봉사자의 자원봉사활동 지속에 영향을 미치는 요인 연구, 이화여자대학교 대학원 석사학위논문, pp.20-66.

17. Gidron, B.(1985), Predictors of Retention and turnover Among Service Volunteer Workers, Journal of Social Service Research Vol.8(1);1-16.

18. 이성록(2001), 자원봉사행동에 대한 다차원적 동 인의 영향력, 서울여자대학교 대학원 박사학위논 문, pp.82-167.

19. 이병순(2004), 노년자원봉사활동의 지속성에 영향 을 미치는 요인에 관한 연구, 경기대학교 대학원 박사학위논문, pp.75-154.

20. 최진희, 임정도(2010), 의료서비스에 대한 환자신 뢰가 관계몰입에 미치는 영향, 보건의료산업학회 지 Vol.4(1);6-10. 